\title{
Aphrodisiacs in the global history of medical thought
}

\author{
Alison M. Downham Moore ${ }^{1,2, *}$ and Rashmi Pithavadian ${ }^{3}$ \\ ${ }^{1}$ School of Humanities and Communication Arts, Western Sydney University, Locked Bag 1797, Penrith NSW 2751, Australia, \\ ${ }^{2}$ Freiburg Institute for Advanced Study, Albert-Ludwigs-Universität, Albertstraße 19, Freiburg im Breisgau 79100, Germany \\ and ${ }^{3}$ School of Health Sciences, Western Sydney University, Locked Bag 1797, Penrith NSW 2751, Australia E-mail: \\ R.Pithavadian@westernsydney.edu.au \\ ${ }^{\star}$ Corresponding author. E-mail: alison.moore@westernsydney.edu.au
}

\begin{abstract}
The study of aphrodisiacs is an overlooked area of global history which this article seeks to remedy by considering how such substances were commercially traded and how medical knowledge of them was exchanged globally between 1600 and 1920 . We show that the concept of 'aphrodisiacs' as a new nominal category of pharmacological substances came to be valued and defined in early modern Latin, English, Dutch, Swiss, and French medical sources in relation to concepts transformed from their origin in both the ancient Mediterranean world and in medieval Islamicate medicine. We then consider how the general idea of aphrodisiacs became widely discredited in mid-nineteenth-century scientific medicine until after the First World War in France and in the US, alongside their commercial proliferation in the context of new colonial trade exchanges between Europe, the US, Southeast Asia, Africa, India, and South America. In both examples, we propose that global entanglements played a significant role in both the cohesion and the discreditation of the medical category of aphrodisiacs.
\end{abstract}

Keywords: aphrodisiacs; colonial exoticism; global history of medicine; history of sexuality; history of sexual science

The study of aphrodisiacs is an overlooked area of global history which this article seeks to remedy by considering how such substances were commercially traded and how medical knowledge of them was exchanged globally between $c .1600$ and $c .1920$. Medical substances have been globally traded as material goods since antiquity. But for just as long, medical knowledge about them has also been exchanged, entailing translation of concepts between different languages and cultures. Medical substances of the past can therefore be studied both through the patterns of commercial trade and through analysis of medical and pharmacological ideas. Aphrodisiac substances are a unique object of the global history of medicine because the power attributed to them (to increase sexual desire or pleasure) has often relied on them coming from far and foreign places.

Our article focuses mainly on the history of medical ideation but also considers the commercial trade in aphrodisiacs as an important underlying context. While excellent research exists on the intercultural history of medical substances and knowledge, none has examined the significant place for purported aphrodisiac substances in medical descriptions of multiple cultures prior to the mid nineteenth century. In the expanding scholarship on the history of scientific global entanglements, the subject of sexual pharmacy is widely ignored even though it was an important field of medicine and pharmacy throughout multiple pre-modern cultures. ${ }^{1}$

\footnotetext{
${ }^{1}$ Londa Schiebinger and Claudia Swan, eds., Science, Commerce, and Politics in the Early Modern World (Philadelphia: University of Pennsylvania Press, 2005); Harold J. Cook, Matters of Exchange: Commerce, Medicine, and Science in the 
Our approach is 'global' in the sense of drawing attention to the intercultural entanglements of medical histories that we argue helped to create the category of aphrodisiacs in European medicine. The exoticism attributed to aphrodisiacs has also underpinned their conceptualization as effective by virtue of their purported rare and potent qualities. We show that the seventeenthcentury Latin term aphrodisiaca, referring to a new nominal category of pharmacological substances, became valued and defined in relation to medical concepts transformed from their origin in both the ancient Mediterranean world and medieval Islamicate medicine. We propose that the conceptual turn in this period toward the creation of the nominal category may have owed much more to the influence of medieval Islamicate medicine than has previously been acknowledged.

We focus on western European aphrodisiacs in relation to the transmission of medical knowledge and trade of substances between Middle Eastern and western European cultures from the end of the sixteenth century. We then consider another major intercultural dimension to aphrodisiacs in the massive late nineteenth-century influx into major metropolitan centres of new African, Indian, Southeast Asian, and South American medicinal products deriving from colonial exploitation. We rethink existing specialist historiography on aphrodisiacs from a long global history perspective. We draw upon Arabic, English, French, German, Dutch, Swiss, and American medical and colonial sources, considering the early modern European emergence of aphrodisiacs as an entire class of substances until the 1920s. Aphrodisiac substances are today commonly defined as those thought to increase sexual desire, genital arousal, or sexual pleasure - a widely accepted, loose definition which we adopt here. ${ }^{2}$ However, the use of a single nominal category defining a class of substances solely as pro-sexual is precisely the novel turn which occurred in the early modern Latin translations of Islamic sexual pharmacy.

Aphrodisiacs have been widely discredited in biomedical thought since the late 1800s, and in current views they appear assigned to a space of triviality. Consequently, global historians have underestimated their importance in the period between the sixteenth and nineteenth centuries as vectors of intercultural transmission of medical understandings of physiology and of larger cultural meanings attributed to sex. By purporting to nourish sexual desire and pleasure, sexual pharmacy has represented an obstacle to moral, medical, and religious discourses of discouragement of sexual pleasure in multiple cultural contexts historically. But it has also helped to shape the very concept that sexual physiology is amenable to chemical manipulation - a notion still underpinning current pharmaceutical pro-sexual products such as Sildenafil and Flibanserin.

Our article incorporates methodologies both of conceptual history of sexuality, which traces long inheritances of ideas across time, ${ }^{3}$ and of global history of medicine, in which the term 'global' is understood as the domain of historical transmissions of medical knowledge, practices, diseases, and products between different parts of the world, often with reference to colonial and imperial power. ${ }^{4}$ We locate our approach on the connectionist spectrum

Dutch Golden Age (New Haven: Yale University Press, 2007); Benthamy Aram, 'Caribbean Ginger and Atlantic Trade, 15701648', Journal of Global History 10 (2015): 410-30; Irina Podgorny, 'The Elk, the Ass, the Tapir, Their Hooves, and the Falling Sickness: A Story of Substitution and Animal Medical Substances', Journal of Global History 13 (2018): 46-68; Matthew Romaniello, 'True Rhubarb? Trading Eurasian Botanical and Medical Knowledge in the Eighteenth Century', Journal of Global History 11 (2016): 3-23; Stephanie Gänger, 'World Trade in Medicinal Plants from Spanish America, 1717-1815', Medical History 59, no. 1 (2015): 44-62.

${ }^{2}$ Frank H. Gawin, 'Pharmacologic Enhancement of the Erotic: Implications of an Expanded Definition of Aphrodisiacs', Journal of Sex Research 14, no. 2 (1978): 107-17; Paola Sandroni, 'Aphrodisiacs Past and Present: A Historical Review', Clinical Autonomic Research 11, no. 5 (2001): 303-7.

${ }^{3}$ Alison M. Downham Moore, 'Temporal Layering in the Long Conceptual History of Sexual Medicine: Reading Koselleck with Foucault', Journal of the Philosophy of History 13, no. 3 (September 2019), https://doi.org/10.1163/18722636-12341428.

${ }^{4}$ Randall M. Packard, The Making of a Tropical Disease: A Short History of Malaria (Baltimore: Johns Hopkins University Press, 2007); Roy Porter, The Greatest Benefit to Mankind: A Medical History of Humanity (London: HarperCollins, 1997); Mark Jackson, A Global History of Medicine (Oxford: Oxford University Press, 2018), Warwick Anderson, Colonial Pathologies: American Tropical Medicine, Race, and Hygiene in the Philippines (Durham, NC: Duke University Press, 
of global historical methodologies, as developed theoretically in the global history of science. ${ }^{5}$ We consider several different cultures which generated knowledge of aphrodisiacs across long time frames because both medical goods and ideas have been globally entangled throughout history, long before the modern era of heightened globalization. ${ }^{6}$ Cultural transmissions occurred temporally via inheritances from ancient Greek medical concepts in both Christianate and Islamicate sources. The relatively longue-durée approach required to locate these transmissions sacrifices some degree of specialist detail. ${ }^{7}$ But it is also crucial for dismantling the common conflation of different medical-historical traditions that have referred to aphrodisiac substances. Such substances in different times did not refer to the same stable object and were translated in and out of knowledge systems of unique temporal and geographic contexts.

Our methodology derives inspiration from recent developments in Middle Eastern gender and sexuality studies which have sharply questioned views of modern sexual medicine focused solely on the global spread of Western science to 'the rest'. Such studies show how ideas about sexuality and its medical treatment have long had entangled and dynamic histories that pre-date both modern colonial pressures on Middle Eastern cultures and the dissemination of modern globalized biomedicine. ${ }^{8}$ Such scholarship tells more complicated stories of the historical exchange of sexual knowledge across Middle Eastern and western European cultures, helping to shape concepts of nationhood, geopolitics, and ideas about cultural 'others'. ${ }^{9}$ More broadly, historians of science have recognized the role of global intellectual entanglements between the twelfth and sixteenth centuries in developing what is still often viewed as a purely Western scientific revolution. ${ }^{10}$ As in other works of global history of sexuality, we consider that a global focus does not imply homogeneity of world cultures, but rather 'interactions and contestations' shaped by both specific local contexts and global knowledge networks. ${ }^{11}$ Historians of sexuality and gender have also recently highlighted how European cultural translations of concepts from Middle Eastern, Asian, and indigenous cultures of North and South America contributed to global ideas about inversion, perversion, and the enumeration of the sexes in the modern era. ${ }^{12}$ Such scholarship

2006); Mike Osbourne, The Emergence of Tropical Medicine in France (Chicago: University of Chicago Press, 2014); David Arnold, ed., Imperial Medicine and Indigenous Societies (Manchester: Manchester University Press, 1988); Jennifer Johnson, 'New Directions in the History of Medicine in European, Colonial and Transimperial Contexts', Contemporary European History 25, no. 2 (2016): 387-99.

${ }^{5}$ Kapil Raj, Relocating Modern Science: Circulation and the Construction of Knowledge in South Asia and Europe, 1650-1900 (Basingstoke: Palgrave, 2007); Sujit Sivasundaram, 'Sciences and the Global: On Methods, Questions and Theory', Isis 101, no. 1 (2016): 146-58; Fa-ti Fan, 'The Global Turn in the History of Science', East Asian Science, Technology and Society: An International Journal 6 (2012): 249-58.

${ }^{6}$ Jackson, Global History of Medicine, 1; Mark Harrison, 'A Global Perspective: Reframing the History of Health, Medicine and Disease', Bulletin of the History of Medicine 89 (2015): 639-89.

${ }^{7}$ David Armitage, 'What is the Big Idea? Intellectual History and the Longue Durée', History of European Ideas 38, no. 4 (2012): 493-507; Frederick L. Holmes, 'The Longue Durée and the History of Science', History and Philosophy of the Life Sciences 24, no. 4 (2003): 463-70.

${ }^{8}$ Lara Deeb and Dina Al-Kassim, 'Introduction', Journal of Middle East Women's Studies 7, no. 3 (2011): 1-5.

${ }^{9}$ Afsaneh Najmabadi, Women with Moustaches, Men without Beards: Gender and Sexual Anxieties of Iranian Modernity (Berkeley: University of California Press, 2005); Dror Ze'evi, Producing Desire: Changing Sexual Discourse in the Ottoman Middle East, 1500-1900 (Berkeley: University of California Press, 2006); Kathryn Babayan and Afsaneh Najmabadi, eds., Islamicate Sexualities: Translations Across Temporal Geographies of Desire (Cambridge, MA: Harvard University Press, 2008).

${ }^{10}$ Toby E. Huff, The Rise of Early Modern Science: Islam, China and the West (Cambridge: Cambridge University Press, 2017); Cook, Matters of Exchange.

${ }^{11}$ Veronika Fuechtner, Douglas E. Haynes, and Ryan M. Jones, 'Toward a Global History of Sexual Science: Movements, Networks, and Deployments', in A Global History of Sexual Science, 1880-1960, ed. Veronika Fuechtner, Douglas E. Haynes, and Ryan M. Jones (Oakland: University of California Press, 2017), 9.

${ }^{12}$ Heike Bauer, ed., Sexology and Translation: Cultural and Scientific Encounters Across the Modern World (Philadelphia: Temple University Press, 2015); Merry Wiesner-Hanks, 'Crossing Borders in Transnational Gender History', Journal of Global History 6 (2011): 357-79; Jana Funke, 'Navigating the Past: Sexuality, Race, and the Uses of the Primitive in Magnus Hirschfeld's Travel Writings', in Sex, Knowledge, and Receptions of the Past, ed. Kate Fisher and Rebecca Langlands (Oxford: Oxford University Press, 2015), 111-34. 
has identified a specific historical role of ideas about sexuality in the emergence of imperial and colonial discourses, noting how European images of colonized peoples were often heavily gendered and sexualized. ${ }^{13}$ Aphrodisiacs in the modern era have undoubtedly been assimilated to these modern colonial forms of exoticization. However, even before the colonial era, they were prized in numerous medical traditions as rare and exotic substances, via the circulation of both medical knowledge and pharmacological substances between different parts of the world.

Aphrodisiac products were subject to tremendous geographic spread in several forms between the sixteenth and early twentieth centuries. Here we consider in particular the transmissions of medical knowledge and aphrodisiac substances occurring between the ancient Mediterranean, the Islamicate medieval world, and early modern Christianate societies, as well as those created via nineteenth-century French, English, and German colonial interactions with cultures of Africa, Southeast Asia, South America, and the Indian subcontinent. Aphrodisiac substances from places deemed exotic featured widely in French and English apothecary descriptions of the seventeenth and eighteenth centuries. In part, this was via their inscription within orientalist and exoticist tropes of European ethnographies, but also because, as precious and potent remedies, aphrodisiacs necessarily had to be rare, not everyday, substances. ${ }^{14}$ The exoticism attributed to such substances appears also to have helped cohere them as a medicinal category designated by the nominal form of the word: 'aphrodisiacs'. This is not merely a semantic difference. The shift from adjectival description to nominal classification also produced a reduction of such remedies purely to their sexual and reproductive effects, in contrast to other world traditions of classing such substances as having aphrodisiac along with numerous other properties. $^{15}$

In failing to acknowledge the Arabic influence on European medicine which helped to produce the very modern concept of aphrodisiacs, historians remain complicit in an orientalist view of world cultures which overlooks important differences between them. Such views construe Europe as the centre from which all knowledge emanates outwards. The cohering and reduction of sexual pharmacy to the nominal early modern category of aphrodisiacs reflects the novel containment of sexual pleasure as a separate field of experience in modern Western conceptions of the body, as described by Michel Foucault. ${ }^{16}$ It also reflects the Christian theological yoking of sex to reproductive imperatives which did not appear in medieval Islamicate sources. ${ }^{17}$ The invention of 'aphrodisiacs', then, represents far more than just an unrecognized circulation of global medical concepts and products. At the same time as Christianate traditions hyper-valued sex with reference to reproduction within marriage, they also separated sexual from other bodily and mystical experiences, differing in two important ways from pre-modern Islamicate traditions. ${ }^{18}$ The transformation of Islamicate sexual pharmacy into the early modern concept of aphrodisiacs is representative of these broader transformations in the modern Western meaning of sex.

\footnotetext{
${ }^{13}$ Ann Laura Stoler, Carnal Knowledge and Imperial Power: Race and the Intimate in Colonial Rule, 2nd ed. (Berkeley: University of California Press, 2011); Robert Aldrich, Colonialism and Homosexuality (London: Routledge, 2002).

${ }^{14}$ Peter Cryle, 'The Substance of Desire: Towards a Thematic History of the Aphrodisiac in Nineteenth-Century French Fiction', Nottingham French Studies 37, no. 1 (1998): 28; Valeria Finucci, "There's the Rub": Searching for Sexual Remedies in the New World', Journal of Medieval and Early Modern Studies 38 (2008): 523-57.

${ }^{15}$ Madeleine Pelner Cosman, 'A Feast for Aesculapius: Historical Diets for Asthma and Sexual Pleasure', Annual Review of Nutrition 3, no. 1 (1983): 1-33.

${ }^{16}$ Michel Foucault, Histoire de la sexualité IV. Les aveux de la chair (Paris: Gallimard, 2018).

${ }^{17}$ Abdelwahab Bouhdiba, La sexualité en Islam (Paris: Presses universitaire de France, 2010).

${ }^{18}$ Ibid., $75-107$.
} 


\section{The global origin of pre-modern aphrodisiacs}

A substantial body of specialist scholarship has traced specific examples of purported aphrodisiacs in numerous cultural contexts. ${ }^{19}$ However, the nominal description of an entire class of substances known as 'aphrodisiacs' designated solely for specific sexual purposes appears only to have emerged in seventeenth-century English, French, and Dutch texts, in the period following the transformation of European medicine and pharmacological practices through contact with Middle Eastern medical traditions and products. Important differences underlay pre-modern medical, eighteenth-century libertine, and nineteenth-century pharmacological uses of the term, which we highlight in this article.

Several scholars, mostly writing in a popular genre, have already considered the long world history of aphrodisiacs by surveying their use in numerous different cultures. ${ }^{20}$ However, these endeavours have lacked attention to the particular linguistic and generic conventions of each historic iteration, and have not considered the global entanglements of knowledge between them. They have homogenized all cultures across time and place as having much the same reasons, degree of motivation, and approaches toward the use of these substances, similarly defined. Nineteenth-century European orientalist texts presented all world traditions of aphrodisiac use within the evocation of exotic and hypersexual colonial subjects, as we discuss later in this article. Current historiographic practices of projecting the European nominal category 'aphrodisiacs' onto all other traditions reflects this generalizing exoticism, ignoring the specific conceptions of sexual pharmacology in diverse human cultures.

Numerous scholars have produced excellent specialist studies of sexual pharmacy in single focused contexts which, when considered together, reveal important variability in their conception across time and place. ${ }^{21}$ Such works demonstrate unique conceptual dimensions, purposes, and applications for such products in every historical context of recorded use. Our contribution here is to propose a relation between several different contexts with unique understandings of sexual pharmacology, explaining their intercultural transmissions both across time (through inheritance of past medical concepts) and across place (both through colonial trade and via transcultural medical-knowledge disseminations). We show that these global dimensions do not merely help

\footnotetext{
${ }^{19}$ Dominic Steavu, 'Buddhism, Medicine, and the Affairs of the Heart: Āyurvedic potency therapy (Vājikarana) and the Reappraisal of Aphrodisiacs and Love Philtres in Medieval Chinese Sources', East Asian Science, Technology and Medicine 45 (2017): 9-48; Nașīr Al-Dīn Al-Ṭūsī, The Sultan's Sex Potions: Arab Aphrodisiacs in the Middle Ages, ed. and trans. Daniel L. Newman (London: Saqi Books, 2014); Shireen Hamza, 'Medicine Beyond Doctors: Aphrodisiac Recipes in Tenth-Century Medicine and Cuisine', Medieval Feminist Forum 53, no. 2 (2018): 91-113, https://doi.org/10.17077/ 1536-8742.2119; Jennifer Evans, Aphrodisiacs, Fertility and Medicine in Early Modern England (London: Royal Historical Society, 2014); Jacqueline Borsje, 'Love Magic in Medieval Irish Penitentials, Law and Literature: A Dynamic Perspective', Studia Neophilologica 84, supp. 1 (2012): 6-23; Donald Harper, 'Ancient and Medieval Chinese Recipes for Aphrodisiacs and Philters', Asian Medicine 1, no. 1 (2005): 91-100; Peter M. Cryle, The Telling of the Act: Sexuality as Narrative in Eighteenth and Nineteenth-Century France (Newark, DE: University of Delaware Press, 2001), 70-97; Cryle, 'Substance of Desire', 27-49; Jan G. R. Elferink, 'Aphrodisiac Use in Pre-Columbian Aztec and Inca Cultures', Journal of the History of Sexuality 9, no. 1/2 (2000): 25-36; Lynn LiDonicci, 'Burning for It: Erotic Spells for Fever and Compulsion in the Ancient Mediterranean World', Greek, Roman, and Byzantine Studies 39, no. 1 (1998): 63-97; Varro E. Tyler, 'Damiana: A History of a Hoax', Pharmacy in History 25, no. 2 (1983): 55-60; Martin Puhvel, 'The Wife of Bath's "Remedies of Love"', Chaucer Review 20, no. 4 (1986): 307-12; Thomas G. Benedek, 'Disease as Aphrodisiac', Bulletin of the History of Medicine 45, no. 4 (1971): 322-40.

${ }^{20}$ Alan Hull Walton, Aphrodisiacs, From Legend to Prescription: A Study of Aphrodisiacs Throughout the Ages (Westport, CT: Associated Booksellers, 1958); Peter V. Taberner, Aphrodisiacs: The Science and the Myth (Philadelphia: University of Pennsylvania Press, 1985); John Riddle, Goddesses, Elixirs and Witches: Plants and Sexuality Throughout Human History (New York: Palgrave, 2010); Sandroni, 'Aphrodisiacs Past and Present'.

${ }^{21}$ Evans, Aphrodisiacs, Fertility and Medicine; Al-Dīn Al-Ṭusī, The Sultan's Sex Potions; Meika Loe, The Rise of Viagra: How the Little Blue Pill Changed Sex in America (New York: New York University Press, 2004); Elferink, 'Aphrodisiac Use'; LiDonicci, 'Burning for It'; Borsje, 'Love Magic in Medieval Irish Penitentials'; Steavu, 'Buddhism, Medicine, and the Affairs of the Heart'; Tyler, 'Damiana', 55-60; Puhvel, 'Wife of Bath's "Remedies of Love"'; Harper, 'Ancient and Medieval Chinese Recipes'; Benedek, 'Disease as Aphrodisiac'; Cryle, Telling of the Act, 70-97.
} 
to characterize past aphrodisiacs for us as historians, but actually helped early modern medicine to cohere the very category to which the noun 'aphrodisiacs' refers. Without the entanglements of European medicine with the already-globalized traditions of the medieval Middle East, the novel elaboration of this class of pharmacy would most probably never have occurred.

In medieval Arabic medicine (c.800-1500 CE), substances deemed to increase sexual desire and pleasure were recommended frequently in a massive corpus of sources described as a form of medical 'erotology'. ${ }^{22}$ This was a unique style of sexual science describing erotic and reproductive physiology in medical terms, known as 'ilm al-bāh. ${ }^{23}$ Here sexual pharmacy was not only considered for improving erections and increasing pleasure and conception in both men and women, as occurred in the later European context. Middle Eastern medical substances were also valued for inhibiting conception, for both preventing and promoting miscarriage, for beautifying the genitalia, for producing specific forms of pleasure, and for increasing sexual desirability. They were widely discussed in more than 150 works; most remain only in manuscript form today. ${ }^{24}$ Pre-modern Latin and Greek sources occasionally also referred to the use of aphrodisiac foods but such examples cannot be compared to the vast medical literature in Arabic which discussed sexual pharmacy within an entire scholarly genre focused on the medical description of sexual matters. ${ }^{25}$ These substances were not classed as a specific nominal category as in the later European designation of 'aphrodisiacs' because in the Arabic sources stimulating desire was not the only role of sexual pharmacy. Even when substances were intended for this purpose, they were thought to have other medicinal properties in addition to their aphrodisiac ones. This suggests that the uniquely coherent category of aphrodisiacs appearing in early modern Europe represented an important conceptual turn in which such substances became reduced purely to their sexual and reproductive properties. ${ }^{26}$

Most existing scholarship has assumed that ancient Greece was the source of early modern English, French, Latin, and Dutch uses of aphrodisiacs. Early modern Christianate scholars, like medieval Islamicate ones, referred frequently to ancient medical traditions of Galenic and Hippocratic medicine. ${ }^{27}$ Yet later scholars elaborated significantly on the ancient Greek knowledge they cited, and little existing scholarship has considered the importance of medieval Islamicate pharmacology as a source of much European knowledge about ancient Greek aphrodisiac usage. ${ }^{28}$

\footnotetext{
${ }^{22}$ Bouhdiba, La sexualité en Islam, 171-93; Daniel L. Newman, 'Arabic Erotic Literature', in Al-Dīn Al-Tūsī, The Sultan's Sex Potions, 15-51.

${ }^{23}$ Bouhdiba, La sexualité en Islam, 171-93; Malek Chebel, L'Érotisme arabe (Paris: Robert Laffont, 2014); Sahar Amer, Crossing Borders: Love Between Women in Medieval French and Arabic Literatures (Philadelphia: University of Pennsylvania Press, 2013); Patrick Franke, 'Before Scientia Sexualis in Islamic Culture: 'ilm al-bāh Between Erotology, Medicine and Pornography', Social Identities 18, no. 2 (2012): 161-73; Elyse Semeridjan, 'Rewriting the History of Sexuality in the Islamic World', Hawwa 4, no. 2-3 (2006): 119-30; Ahmed Ragab, 'One, Two, or Many Sexes: Sex Differentiation in Medieval Islamicate Medical Thought', Journal of the History of Sexuality 24, no. 3 (2015): 428-54; Newman, 'Arabic Erotic Literature'; Babayan and Najmabadi, eds., Islamicate Sexualities; Peter E. Porman, 'Female Patients and Practitioners in Medieval Islam', Lancet 373, no. 9675 (2009): 1598-9.

${ }^{24} \mathrm{~A}$ few of those that have been translated into English directly from Arabic include: Al-Dīn Al-Tūsī, The Sultan's Sex Potions; Shihab al-Din al-Nuwayri, The Ultimate Ambition in the Arts of Erudition: A Compendium of Knowledge From the Classical Islamic World, ed. and trans. Elias Muhanna (London: Penguin Classics, 2016); Muhammad ibn 'Umar al-Nafzāwī, The Perfumed Garden of Sensual Delight (Ar-rawd al-âtir fî nuzhati'l khâtir), trans. Jim Colville (London: Kegan Paul, 1999); The Medical Formulary or Aqrābādhin of Al-Kindī, trans. Martin Levey (Madison: University of Wisconsin Press, 1966).

${ }^{25}$ Madeleine Pelner Cosman, 'Machaut's Medical Musical World', Annals of the New York Academy of Sciences 314 (1978): $1-36$.

${ }^{26}$ Charles Perry, 'Appendix', in A Soup for the Qan: Chinese Dietary Medicine of the Mongol Era as Seen in Hu Szu-Hui's Yin-Shan Cheng-Yao, ed. Paul D. Buell and Eugene N. Anderson (London: Routledge, 2009), 126.

${ }^{27}$ Lauren Kassell, 'Medical Understandings of the Body, 1500 to the Present', in The Routledge History of Sex and the Body, c.1500-1750, ed. Sarah Toulalan and Kate Fisher (London: Routledge, 2013), 57-82.

${ }^{28}$ Zohar Amar and Efraim Lev, Arabian Drugs in Early Medieval Mediterranean Medicine (Edinburgh: University of Edinburgh Press, 2017).
} 
The very adjective 'aphrodisiac', though derived from the name of the ancient Greek goddess of love Aphrodite, was not in fact an ancient word itself. It appears to have derived from the eleventh-century Tunisian scholar known as Constantinus Africanus (c.1020-1099 CE), who translated several works of Galen and Hippocrates from Arabic sources into Latin, and wrote a Latin work of sexual medicine, De coitu, which included a long section dealing with foods and herbs in Arabic medicine thought to stimulate sexual desire. Although Constantinus attributed no specific Arabic source for this work, as Charles Burnett and Danielle Jacquart note, it appears to be based on the work of the Arab physician d'Ibn al-Ğazzār (Ibn al-Jazzar, 898-980 $\mathrm{CE})$, several of whose other works Constantinus translated into Latin. ${ }^{29}$ The Persian Nașī al-Dīn al-Ṭusī (1201-74) was another medieval Islamic physician who wrote about aphrodisiac remedies in Arabic, in works such as the Kitab albāb al-Bāhiyya wa 'l-tarākīb al-sultāniyya, translated as The Book of Choice Sexual Stimulants and the Sultan's Mixtures. ${ }^{30}$ Reference to aphrodisiac remedies is also found in general Arabic medical and philosophical texts such as the 1423 'nhāïï al-ādrāk ū ag̉āẹ mn aqrābādīn al-ānqrābādīnāt' ('On the limits of cognition and the purpose of approximation') of Dā'oūd ibn Nāșir al-Aghbarī, indicating a mainstream place for sexual pharmacy in Islamicate medical cultures. ${ }^{31}$ It is unclear how many such Arabic sources circulated in medieval Europe, but important works of European medicine such as the twelfth-century Trotula integrated ideas about women's physiology derived from these texts. ${ }^{32}$ However, the concept of a distinct category of substances prescribed by physicians for this purpose emerged only in the seventeenth century with the invention of the new Latin noun: Aphrodisiaca. ${ }^{33}$

Several scholars have noted transformations of European medicine from the late sixteenth century in response to translations into Latin of Arabic and Persian medical texts by scholars such as the tenth-century Persian polymath Rhazes (Abūbakr Mohammad-e Zakariyyā-ye Rāzī, 854-925 CE) and the eleventh-century Persian physician Avicenna (Ibn Sina, 980-1037 CE). ${ }^{34}$ While Islamicate traditions appeared not to cohere aphrodisiac substances into a specific nominal category as occurred in early modern European sources, such substances were subjected to sustained medical attention in hybridized works devoted to sexual matters and circulating in early modern Europe, such as Constantinus' De coitu. Arabic and Persian translations from ancient Greek of the works of Hippocrates also impacted the development of ideas about sexual anatomy in this same period. Importantly, this development contributed to the first European medical descriptions of the clitoris and its role in women's sexual physiology in the work of the sixteenth-century Milanese anatomist Realdo Colombo. ${ }^{35}$ But, as George Saliba and others have demonstrated, medieval Islamicate scholars did not merely transmit the lost knowledge of the ancient Greeks, but integrated medical insights from Indus valley, Greek, Syrian,

\footnotetext{
${ }^{29}$ Charles S. F. Burnette and Danielle Jacquart, eds., Constantine the African and 'Alī Ibn Al-'Abbas Al-Mağūsī: The Pantegni and Related Texts (Leiden: Brill, 1994), 243.

${ }^{30}$ Daniel L. Newman, 'The Sultan's Potions', in Al-Dīn Al-Ṭūsī, The Sultan's Sex Potions, 63-84.

${ }^{31}$ Dā'oūd ibn Nāṣir al-Aghbarī, 'nhāï al-ādrāk ū ag̉rād mn aqrābādīn al-ānqrābādīnāt' ('On the limits of cognition and the purpose of approximation'), Arabe 2970, Département des manuscrits, Bibliothèque nationale de France, Paris.

${ }^{32}$ Newman, 'Arabic Erotic Literature', 54; Monica H. Green, ed. and trans., The Trotula: A Medieval Compendium of Women's Medicine (Philadelphia: University of Pennsylvania Press, 2001).

${ }^{33}$ Evans, Aphrodisiacs, Fertility and Medicine, 6.

${ }^{34}$ Ingrid Hehmeyer and Khan Aliya 'Islam's Forgotten Contributions to Medical Science', Canadian Medical Association Journal 176, no. 10 (2007): 1467-8; Huff, Rise of Early Modern Science; Azeem Majeed, 'How Islam Changed Medicine', British Medical Journal 331 (2005): 1486-7.

${ }^{35}$ Realdo Colombo, De re anatomica (On the Subject of Anatomy) (Venice: Nicolai Beuilaquae, 1559), 448; Katherine Park, 'The Rediscovery of the Clitoris: French Medicine and the Tribade, 1570-1620', in The Body in Parts: Fantasies of Corporeality in Early Modern Europe, ed. David Hillman and Carla Mazzio (New York: Routledge, 1997), 171-93; Alison M. Moore, 'Victorian Medicine Was Not Responsible for Repressing the Clitoris: Rethinking Homology in the Long History of Women's Genital Anatomy', Signs: The Journal of Women in Culture and Society 44, no. 1 (2018): 57-8; Silvie Chaperon, “Le trône des plaisirs et des voluptés": anatomie politique du clitoris, de l'antiquité à la fin du XIXième siècle', Cahiers d'histoire 118 (2012): 41-60.
} 
Babylonian, and Persian traditions, developing original contributions to scientific thought between the tenth and fifteenth centuries, with significant - though often denied - effects on the European Renaissance. ${ }^{36}$

European pharmacy practice was also transformed between the thirteenth and sixteenth centuries by intensified spice trade between Asia, the Middle East, and western Europe, particularly following increased commercial exchange after fifteenth-century Muslim traders extended shipping routes from East Asia to India, through the Persian Gulf and then overland into Europe. ${ }^{37}$ Though partially hindered by the fifteenth-century Crusades, a further revival of the spice trade in the sixteenth century renewed commerce between the Middle East and the Mediterranean. ${ }^{38}$ This trade brought many new purportedly aphrodisiac substances into European markets, including spices such as cinnamon and pepper, botanicals such as salep and opium, and rare animal products, such as deer musk and whale-derived ambergris, which were all thereafter commonly described as aphrodisiacs in seventeenth- and eighteenth-century European apothecary lists, such as those of Cullen, Tissot, and Brookes. ${ }^{39}$ Early manuscripts of Arab pharmacopoeia described in Latin texts by the end of the eleventh century had already primed medieval European pharmacists for the reception of many rare and novel substances from the Middle East, several centuries before such goods became widely available through the spice trade. ${ }^{40}$ Although some of these products had been obscurely known to European pharmacists for many centuries, they had hitherto been scarce and more often the stuff of legend than of active prescription.

Opium is a clear example of a substance circulating in several world cultures since antiquity and so assimilable to standard European narratives of ancient Greek inheritance. However, it was only valued as an aphrodisiac in Christianate cultures after their contact with medieval Islamicate medicine. Its entry into modern European medicine as both an analgesic and an aphrodisiac derived from its widespread use in medieval Persian traditions. It was brought to Europe by the eclectic Swiss chemist Paracelsus (1493-1541) following his travels in the Middle East in the mid sixteenth century and his emphatic promotion of the poppy thereafter. ${ }^{41}$ The sixteenth-century Portuguese physician Garcia da Orta noted the paradox of its reputation in medieval European medicine as inducing impotence in men, while it was prized for stimulating 'fleshly lusts' in Indian, Persian, and Arabic medicine. He thought both were true, since opium slowed men's arousal and made them better synchronized to women's slower sexual response, which allowed the couple to expel their seeds simultaneously. ${ }^{42}$ Ambergris was also known to the ancient Greeks and to the Romans. However, following its substantial exploitation by fifteenth-century Muslim traders sailing between India and the Mediterranean, it became widely valued in European pharmacy as an aphrodisiac. Ambergris even became uniquely

\footnotetext{
${ }^{36}$ George Saliba, Islamic Science and the Making of the European Renaissance (Cambridge, MA: MIT Press, 2007).

${ }^{37}$ Fred Czarra, Spices: A Global History (London: Reaktion Books, 2009); Gary Paul Nabhan, Cumin, Camels, and Caravans: A Spice Odyssey (Berkeley: University of California Press, 2014).

${ }^{38}$ Frederic C. Lane, 'The Mediterranean Spice Trade: Further Evidence of Its Revival in the Sixteenth Century', American Historical Review 45 (1939): 581-90.

${ }^{39}$ William Cullen, Lectures on the Materia Medica (Dublin: Thomas Ewing, 1773), 60; Samuel Auguste David Tissot, L'Onanisme. Dissertation sur les maladies produits par la masturbation, 3rd ed. (Lausanne: Marc Chapuis, 1769; orig. ed. 1760), 259; Richard Brookes, An Introduction to Physic and Surgery (London: J. Newberry, 1754), 500.

${ }^{40}$ Monica H. Green, 'Medical Books', in The European Book in the Twelfth Century, ed. Erik Kwakkel and Rodney Thomson (Cambridge: Cambridge University Press, 2018), 277-92.

${ }^{41}$ John H. Halpern and David Blistein, Opium: How an Ancient Flower Shaped and Poisoned the World (New York: Hachette, 2019), 49-52; Andrew Cunningham, 'Paracelsus Fat and Thin: Thoughts on Reputations and Realities', in Paracelus: The Man and His Reputation, His Ideas and Their Transformation, ed. Ole Peter Grell (Leiden: Brill, 1998), 76.

${ }^{42}$ Garcia da Orta, Colloquies on the Simples and Drugs of India, trans. Conde de Ficalho and Sir Clements Markham (London: Henry Sotheran, 1914; orig. Spanish ed. 1563), 331-2.
} 
fetishized by European royalty as an exotic luxury product throughout the sixteenth to eighteenth centuries. ${ }^{43}$

The earliest European uses of the noun aphrodisiaca - as a class of remedies thought to stimulate sexual vigour and conception - appeared in Latin medical texts during this period of intercultural influence, such as in the Swiss physician Théophile Bonet's Latin Mercurius compitalitius of 1682, with the word appearing in English translation in the 1684 version of this work published in London. ${ }^{44}$ The noun 'aphrodisiacs' then began to appear in early eighteenthcentury English works of physicians and surgeons, such as John Jones (1700), John Marten (1709), and Thomas Fuller (1710), ${ }^{45}$ and in French works of the mid eighteenth century, such as the Swiss physician Samuel Tissot's treatise on masturbation, L'Onanisme (1760), which cited benefits of opium for stimulating sexual desire. ${ }^{46}$ In part, this reflected the significantly expanded pharmacopoeia of substances that could now be listed under such a class. However, it is also likely that the exotic origins of many newly available, particularly aromatic, substances helped to cohere the category through a new mystique attached to such products.

Our reading of early modern Latin, French, English, and Dutch sources found no references to the prescription of aphrodisiacs aimed at same-sex relations. As global historians of science have noted, transmissions of knowledge across cultures are rarely equal, consistent, or reciprocal, as implied by the terms 'flow' and 'circulation' widely used among global historians. ${ }^{47}$ One important transformation of knowledge about aphrodisiac substances in their crossing between Islamicate and Christianate cultures of the medieval period was a new insistence in the European context on aphrodisiacs as medically legitimate purely in relation to procreative sex. Scholars of same-sex desire in early modern Spain note the circulation of Arabic sources referring to the use of aphrodisiacs in love between women. ${ }^{48}$ It is also likely, given the importance of male homoerotic poetry in the early modern Middle East, that aphrodisiacs in that context were used for purposes of increasing pleasure in same-sex relations. ${ }^{49}$ The period in which aphrodisiacs as a class of substance entered medical texts in Latin, English, Dutch, and French coincided with some of the first major persecutions of same-sex communities, such as the mass arrests of sodomites in seventeenth- and eighteenth-century England, Switzerland, and Holland. ${ }^{50}$ Catholic theology from late antiquity onwards explicitly condemned same-sex relations, along with most other sexual practices that were not strictly procreative. ${ }^{51}$ This undoubtedly discouraged medical scholars of the early modern period from discussing aphrodisiac usage beyond the man-woman binary and outside matrimony. Consequently, while Arabic sources considered sexual remedies

\footnotetext{
${ }^{43}$ Robert Clarke, The Origin of Ambergris', Latin American Journal of Aquatic Mammals 5, no. 1 (2006): 7-21; Sophie Read, 'Ambergris and Early Modern Languages of Scent', Seventeenth Century 28, no. 2 (2013): 221-37; Christopher Kemp, Floating Gold: A Natural (and Unnatural) History of Ambergris (Chicago: University of Chicago Press, 2012).

${ }^{44}$ Théophile Bonet, Mercurius Compitalitius, sive Index medico-practicus (Geneva: L. Chouët, 1682), 777-8; Théophile Bonet, Mercurius Compitalitius: or, A Guide to the Practical Physician (London: Thomas Flesher, 1684), 694-5.

${ }^{45}$ Evans, Aphrodisiacs, Fertility and Medicine, 4; John Jones, The Mysteries of Opium Reveal'd (London: Richard Smith, 1700), 52; John Marten, Gonosologium Novum: or, a New System of All the Secret Infirmities and Diseases, Natural, Accidental, and Venereal in Men and Women (London: N. Crouch, 1709), 49; Thomas Fuller, Pharmacopoia Extemporanea: or, A Body of Prescripts (London: Ben J. Walford, 1710), 133.

${ }^{46}$ Tissot, L'Onanisme, 259.

${ }^{47}$ Kapil Raj, 'Beyond Postcolonialism ... and Positivism: Circulation and the Global History of Science', ISIS 104, no. 2 (June 2013): 337-47; Fan, 'Global Turn in the History of Science', 251-2.

${ }^{48}$ Sherry Marie Velasco, Lesbians in Early Modern Spain (Nashville: University of Vanderbilt Press, 2011 ), 17.

${ }^{49}$ Thomas Bauer, 'Male-Male Love in Classical Arabic Poetry', in The Cambridge History of Gay and Lesbian Literature, ed. E. L. McCallum and Mikko Tuhkanen (Cambridge: Cambridge University Press, 2014), 107-24.

${ }^{50}$ Helmut Puff, Sodomy in Reformation Germany and Switzerland, 1400-1600 (Chicago: University of Chicago Press, 2003); Theo Van de Meer, 'Sodomy and the Pursuit of a Third Sex in the Early Modern Period', in Third Sex, Third Gender: Beyond Sexual Dimorphism in Culture and History, ed. Gilbert Herdt (New York: Zone Books, 1993).

${ }^{51}$ Elizabeth B. Keiser, Courtly Desire and Medieval Homophobia: The Legitimation of Sexual Pleasure in 'Cleanness' and Its Contexts (New Haven: Yale University Press, 1997); Ruth Mazo Karras, Sexuality in Medieval Europe: Doing Unto Others (New York: Routledge, 2005).
} 
from multiple perspectives that were not merely procreative, this broader sense was not assimilable to Christianate engagements owing to the insistence in pre-modern Christianity that all sex should serve reproduction.

\section{Early modern European aphrodisia}

In early modern European and Arabic medical texts, aphrodisiac medicaments were prescribed to both men and women in the view that both sexes' pleasure mattered to conception, which derived from Galenic and Hippocratic medicine. ${ }^{52}$ This was a period marked everywhere with overall low life expectancy and high infant mortality. ${ }^{53}$ Consequently, fertility was a central medical concern, given that most families struggled to raise enough children to meet labour demands in small-scale farming lifeways. ${ }^{54}$ According to Galen of Pergamon (129-c.216 CE) and other ancient scholars considered authoritative in both early modern European and medieval Islamicate medicine, both man and woman must eject their seed during sexual intercourse for conception to occur, and this expulsion, symbolized by the peak of pleasure, should preferably occur at around the same time. ${ }^{55}$ In the context of such medical concepts about reproduction, the category of aphrodisiacs as a distinct class of substances cohered in Europe, aiming to improve sexual pleasure and orgasm in both men and women, in the belief that this would ensure conception. ${ }^{56}$

Protestant teachings cited the Bible's direction to be fruitful and multiply within the boundaries of marriage, in contrast to medieval Catholic theology, which discouraged sexual pleasure in marriage even as it acknowledged the necessity of reproductive sex. ${ }^{57}$ According to Protestant theological discourse, married couples must engage in pleasurable sexual intercourse to produce healthy offspring. ${ }^{58}$ The sixteenth-century Dutch physician Laevinus Lemnius even thought that failing to enjoy reproductive sex would result in slothful and stupid children. ${ }^{59}$ Married couples thus likely sought and used aphrodisiacs at this time, which is not to say that single, samesex-desiring, and non-binary people did not also use them. Many early modern medical sources certainly also described same-sex couples and third sexes referred to as hermaphrodites, about which there is a substantial body of scholarship. ${ }^{60}$ But the Church officially condemned samesex relations in this period far more categorically than other contemporaneous religions. Consequently, works of medicine produced in Christianate cultures avoided discussing samesex desire and emphasized aphrodisiacs as a category of pharmacology to stimulate sexual pleasure and conception within marriage. ${ }^{61}$ There is no indication in such early modern medical texts that aphrodisiacs were intended purely for sexual pleasure per se, nor that they targeted ageing men's erectile capacity in particular, as became common in twentieth-century pro-sexual pharmacy.

\footnotetext{
${ }^{52}$ Evans, Aphrodisiacs, Fertility and Medicine, 72-3.

${ }^{53}$ E. A. Wrigley and R. S. Schofield, The Population History of England 1541-1871: A Reconstruction (London: Edward Arnold, 1981), 161.

${ }^{54}$ Taberner, Aphrodisiacs, 41.

${ }^{55}$ Thomas Laqueur, Making Sex: Body and Gender from the Greeks to Freud (Cambridge, MA: Harvard University Press, 1990), 46; Evans, Aphrodisiacs, Fertility and Medicine, 58-9.

${ }^{56}$ Evans, Aphrodisiacs, Fertility and Medicine, 79.

${ }^{57}$ Patricia Crawford, Blood, Bodies and Families in Early Modern England (New York: Routledge, 2014), 55-6; Pierre Payer, The Bridling of Desire: Views of Sex in the Later Middle Ages (Toronto: University of Toronto Press, 1993).

${ }^{58}$ Crawford, Blood, Bodies and Families, 56.

${ }^{59}$ Laevinus Lemnius, The Secret Miracles of Nature: In Four Books (London, Jo Streater, 1658; orig. Latin ed. 1559$), 12$.

${ }^{60}$ Alison M. Moore, 'Historical Sexes', in Global Encyclopedia of Lesbian, Gay, Bisexual, Transgender, and Queer (LGBTQ) History, ed. Howard Chiang (Farmington Hills, MI: Charles Scribner's Sons, 2019), 671-7; Herdt, ed., Third Sex, Third Gender; Valerie Traub, The Renaissance of Lesbianism in Early Modern England (Cambridge: Cambridge University Press, 2002).

${ }^{61}$ For comparison of early modern Islamicate and Christianate sources on homosexuality, see Khaled El-Rouayheb, Before Homosexuality in the Arab-Islamic World, 1500-1800 (Chicago: University of Chicago Press, 2009); and Tom Betteridge, ed., Sodomy in Early Modern Europe (Manchester: Manchester University Press, 2002); Evans, Aphrodisiacs, Fertility and Medicine, 17.
} 
Medieval and early modern herbalists classified substances as having aphrodisiac effects according to either the humoral model or to the 'doctrine of signatures', referring to the physicians of antiquity Dioscorides (c.40-90 CE) and Galen (129-c.201 CE). ${ }^{62}$ Islamicate Arabic and Persian sources, as well as European Latin and Hebrew sources, all referred to the humoral model in describing recipes for stimulating sexual desire and facilitating pregnancy, most likely owing to their common inheritances from Galenic and Hippocratic medicine. ${ }^{63}$ Conversely, according to the doctrine of signatures or sympathetic treatment, plant and animal components resembling parts of the human body were seen as medicaments for treating ailments of those bodyparts. ${ }^{64}$ It may seem that a pure continuity existed here between ancient and early modern medical ideas about aphrodisiacs according to the doctrine of signatures. This is one reason why casual approaches to the world history of aphrodisiacs have tended to collapse the differences between them. However, early modern medical writers engaged in novel mediations with ancient sources, instantiating their own authority through claims of ancient inheritance while also innovating substantially. ${ }^{65}$ The doctrine of signatures was particularly associated with Paracelsus and with his follower the sixteenth-century German Protestant theologian Jakob Böhme (1575-1624). ${ }^{66}$

Discussion of the satyrion root, or ragwort (Jacobaea vulgaris), exemplifies how aphrodisiacs transmitted into European medicine from Islamicate traditions were often instantiated by appeal to ancient Greek authority. Satyrion was widely thought to resemble the erect penis and testes of the male genitalia, making it a leading doctrine of signatures cure for men's impotence in northern Europe in the early seventeenth century, purportedly since ancient times. ${ }^{67}$ Its name appears to be derived from the Greek myth of the libidinous satyr, and benefited from association with the Roman comic text the Satyricon of Petronius (c.60 CE), in which characters consumed a satyrion drink to enable their sexual endurance. ${ }^{68}$ Satyrion is also the name given to a class of general stimulant plants (not specifically sexual) by the first-century Roman natural philosopher Pliny the Elder, though it is unclear to which plant this referred. In the same paragraph of his Latin Naturalis Historiae mentioning this, Pliny also discussed other plants such as tithymalos, prized by the Greeks for increasing sexual endurance by virtue of its resemblance to male genitalia, about which Pliny personally expressed doubt. ${ }^{69}$ Early modern writers also referred to the Greek physician Dioscorides' Materia medica of 65 CE as the source of ancient use of satyrion. This widely cited text of ancient pharmacy was first translated from Greek into Syrian by Gabriel b. Bocht-Ichō1 (court physician for both the Calif Harun Al-Rashid and the Calif Al-Ma'mun in the ninth century), and numerous Arabic translations were made between the ninth and fourteenth centuries. ${ }^{70}$ However, the association of the Jacobaea vulgaris plant with aphrodisiac qualities and its designation as satyrion appeared only in sixteenth-century Europe, following a revival of Dioscorides through contact with Islamic sources. Jacobaea vulgaris is described in Jean Ruel's 1552 Latin rendition of

\footnotetext{
${ }^{62}$ Taberner, Aphrodisiacs, 42-3.

${ }^{63}$ Al-Dīn Al-Ṭūsī, The Sultan's Sex Potions; Ron Barkai, A History of Jewish Gynaecological Texts in the Middle Ages (Leiden: Brill, 1998), 82; Evans, Aphrodisiacs, Fertility and Medicine, 88, 116.

${ }^{64}$ Porter, Greatest Benefit to Mankind, 200-10.

${ }^{65}$ David Cantor, 'Introduction: The Uses and Meanings of Hippocrates', in Reinventing Hippocrates, ed. David Cantor (Abingdon: Routledge, 2016), 1-20.

${ }^{66}$ Jakob Böhme, De Signatura Rerum: das ist von der Geburt und Bezeichnung aller Wesen: wie alle Wesen aus einem einigen Mysterio urständen (Amsterdam, 1682; orig. ed. 1621).

${ }^{67}$ Evans, Aphrodisiacs, Fertility and Medicine, 117-26; Walton, Aphrodisiacs, 29.

${ }^{68}$ Petronius, Satyricon, in Petronius Arbiter, ed. Michael Heseltine (London: William Heinemann, 1913).

${ }^{69}$ Pliny the Elder, Naturalis Historia, ed. Karl Friedrich Theodor Mayhoff (Leipzig: Teubner, 1906), 1.60.26.

${ }^{70}$ Rifat Vedat Yildram, 'Studies on De materia medica of Dioscorides in the Islamic Era', Asclepio. Revista de Historia de la Medicina y de la Ciencia 65, no. 1 (2013): 1-7.
} 
Dioscorides, and in both a 1555 Spanish translation and a 1559 French translation, with detailed illustrations indicating it to refer to Jacobaea vulgaris. ${ }^{71}$

And so the 'ancient Greek' pedigree of this plant was born. Modern editions of the Materia medica based on early modern translations have obscured this origin, but Lily Beck's recent translation from the ancient Greek manuscript shows satyrion to refer here to man orchis (Fritallaria graeca L.), not Jacobaea vulgaris. ${ }^{72}$ A further doctrine of signatures elaboration of it occurred in seventeenth-century medicine too, which was also not part of the ancient Greek original. Both Oswald Croll and John Marten referred to satyrion roots that were red on the outside and white on the inside, resembling the healthy, fleshy testes exterior with white semen inside, as especially efficacious aphrodisiacs to excite lust. ${ }^{73}$ Clearly something other than the ancient Greek allusions helped these concepts to cohere.

Aphrodisiacs continued to be sold by European apothecaries from 1700 to 1900, but most were also still viewed as having other medical properties rather than being specific for sexual purposes. Nonetheless, the noun that had first become accepted in a small corpus of medical works to refer to substances with such properties now entered common usage in a much wider corpus of medical, literary, and philosophical works from the 1750s, and referred to an array of such purported substances, alongside a new discernment about which could be considered legitimate. ${ }^{74}$ A work by the English physician Richard Brookes (1721-63) published in 1754 referred to several herbal medicaments as having aphrodisiacal properties, such as Erùca (rocket), and Eryngium (sea holly), which he advised 'may be eaten at pleasure'. ${ }^{75}$ Ambergris, used in perfumes, was 'aphrodisiac, cordial and strengthens the nervous system'. ${ }^{76}$ But Brookes dismissed other substances commonly thought to have aphrodisiacal properties, such as satyrion and crushed ants. ${ }^{77} \mathrm{He}$ exemplified the appropriate disposition for medical scholars from the eighteenth century to the mid nineteenth with regard to aphrodisiac substances: he did not debunk the very concept of them per se (as occurred in the later nineteenth century), nor did he promote them as the universal solution to ageing libidos (as occurred in the twentieth). Instead, he distinguished those which he thought truly efficacious, separating popular hearsay from medical wisdom.

William Cullen demonstrated a similar approach to the question of aphrodisiac substances in his Lectures on the Materia Medica of 1773. Here he addressed several exotic plant remedies reputed to have such properties, all deriving from the spice trade. Turkish salep produced an excellent 'mucilaginous drink', but he had little faith in its purported aphrodisiac qualities. ${ }^{78}$ Asian ginseng was useless; the belief in its aphrodisiacal potency rested on 'the most tender, and indeed, absolutely false foundation' ${ }^{79}$ On the other hand, discussing the properties of various European vegetables and fungi, he remarked that the truffle 'commonly said to be possessed of aphrodisiac virtues, is perhaps the only one which has any title to them'. ${ }^{80}$ The renowned early nineteenth-century French gastronomist Brillat-Savarin also devoted several pages in his 1825 Physiologie du gout (Physiology of taste) to the subject of the aphrodisiacal properties of truffles - what he called their 'erotic virtue'. He recounted a story told to him by a 'virtuous

\footnotetext{
${ }^{71}$ Dioscorides Pedanius, Pedanii Dioscoridis Anazarbei. De medicinali materia libri sex, trans. Jean Ruel (Lyon: apud Balthazarem Arnolletum, 1552), unpaginated; Dioscorides, Pedacio Dioscorides Anazarbeo. Acerca de la materia medicinal $y$ de los venenos mortiferos (Antwerp: Iuan Latio, 1555), 355; Dioscorides, Les six livres de pedacion Dioscoride d'Anazarbe de la matiere médiniale (Lyon: Thibault Payan, 1559), 321.

${ }^{72}$ Dioscorides, De materia medica, trans. Lily Y. Beck (Hildesheim: Olms-Weidman, 2017), 237.

${ }^{73}$ Oswald Croll, A Treatise of Oswaldus Crollius of Signatures (London: Starkey, 1669), 5-6; Marten, Gonosologium Novum, 46.

${ }^{74}$ Fuller, Pharmacopoeia Extemporanea, 114.

${ }^{75}$ Brookes, Introduction to Physic and Surgery, 518; Kemp, Floating Gold.

${ }^{76}$ Brookes, Introduction to Physic and Surgery, 500.

${ }^{77}$ Ibid., 545, 524.

${ }^{78}$ Cullen, Lectures on the Materia Medica, 60.

${ }^{79}$ Ibid., $233-4$.

${ }^{80}$ Ibid., 56.
} 
woman' who claimed that she had to defend herself from the uncharacteristic sexual advances of an invited guest and friend of her husband's after serving him a dish of truffled chicken. In retrospect, she was puzzled that she herself had not more emphatically rejected his advances. The story was presented to demonstrate that truffles could 'on certain occasion, render women more tender and men more friendly' ${ }^{81}$

In the eighteenth century, aphrodisiacs had already begun appearing in other genres outside the medical and pharmacological corpus, featuring frequently in works of erotic fiction which began proliferating in this period. ${ }^{82}$ Here the notion of specific substances used solely for the purpose of stimulating sexual pleasure appeared most clearly. The concept of aphrodisiacs was regularly evoked in French libertine fictional works of the late eighteenth and early nineteenth centuries. They were never attributed a central role in encapsulating or causing sexual desire or pleasure, but were viewed merely as assisting in the physiological execution of pleasurable acts. ${ }^{83}$ The marquis de Sade had been arrested for poisoning and sodomy in 1772 after feeding some sort of black aphrodisiac pastilles to two prostitutes whom he had hired, causing them to become violently ill. ${ }^{84}$ There is no evidence of what the pastilles contained, though nineteenth-century commentators assumed them to be cantharides-based (Spanish fly) and mythologized the incident as such. ${ }^{85}$

Various aphrodisiac preparations were available from French apothecaries until the late nineteenth century, such as tablette de magnanimite (magnanimity tablets), electuaire satyrion (satyrion orchid electuary) and poudre de foie (liver powder). ${ }^{86}$ In contrast to medieval aphrodisiacs, which included locally sourced and common foods alongside the new products derived from the spice trade, substances valued as aphrodisiacs in European pharmacies of the late eighteenth and nineteenth centuries were always characterized as rare and exotic. In French and English sources of this time, cantharides was always said to come from either Spain, Naples, or China and to be imbued with the hot, wild, and exotic quality of those places relative to northern Europe. ${ }^{87}$ This theme of aphrodisiacs as potent by virtue of their exotic origins was to become a central motif in late nineteenth-century colonially derived substances.

\section{The colonial boom of exotic remedies and the medical denial of aphrodisiacs}

Over the course of the nineteenth century there was a massively greater availability of traditional medicinal products from India, the Middle East, South America, Southeast Asia, and Africa. This was a result of European colonial expansion and global trade, which produced a powerful stimulus for the European pharmacy of aphrodisiacs in spite of (or perhaps related to) a new official medical scepticism about them. References to Arabic and Persian aphrodisiac substances had occurred in European medical texts since the sixteenth century, as we have seen. But, in the nineteenth century, there was both an expanded global trade of such substances and new orientalist

\footnotetext{
${ }^{81}$ Jean Anthelme Brillat-Savarin, Physiologie du gout (Paris: Lacour, 1825), 20-1. All quoted passages from French sources in this article are Alison Downham Moore's translations.

${ }^{82}$ Lynn Hunt, ed., The Invention of Pornography, 1500-1800: Obscenity and the Origins of Modernity (New York: Zone Books, 1993).

${ }^{83}$ Cryle, 'Substance of Desire', 33.

${ }^{84}$ Jean-Jacques Pauvert, Sade vivant (Paris: Laffont, 1986), 262.

${ }^{85}$ Cryle, 'Substance of Desire', 28.

${ }^{86}$ Aphrodisiacs, Their Nature, History and Uses', in Stories from the Folk-Lore of Russia. Rouskiya Zavetnuiya Skazki, Done into English by the Translator of The Book of Exposition in the Science of Coition, The Old Man Young Again, and Other Charming Works (Paris: Charles Carrington, 1897), reprinted in A. F. Niemoeller, ed., The Nature, History, and Uses of Aphrodisiacs: An Account of the Medicaments and Agents Held to be Provocative of Sexual Desire (Girard, KS: HaldemanJulius Publications, 1948), 5-22 (reference from p. 6).

${ }^{87}$ Denis Diderot and Jean-Baptiste d'Alembert, Encyclopédie méthodique, vol. 10: Médicine (Paris: Agasse, 1821; orig. ed. 1738), 443; John Davenport, Aphrodisiacs and Anti-Aphrodisiacs: Three Essays on the Powers of Reproduction (London: privately printed, 1869), 96.
} 
translations of Islamicate and Indian medical texts describing them. From the late nineteenth century onwards, European scholars developed an exoticist erotic discourse about the Arab world exemplified by the English explorer Sir Richard Burton's 1885-88 translations of both The Arabian Nights and The Perfumed Garden - the latter based on a sixteenth-century erotic text by the Tunisian writer Muhammad ibn 'Umar al-Nafzāwī, which was translated from Arabic into French between 1848 and 1850 by a French colonial officer known only as le Baron R. ${ }^{88}$

The Indian subcontinent, too, became an object of exoticist fantasy for European writers in this period. ${ }^{89}$ In the nineteenth century, multiple non-European cultures were characterized as promiscuous, hypersexual, and perverse in contrast to the purported sexual constraint and moral rectitude of Europeans..$^{90}$ Burton was also the translator of the ancient Sanskrit erotology work of Vātsyāyana, The Kama Sutra, and famously mapped same-sex practices, sexual excess generally, and the use of aphrodisiacs to a specific geographic 'Sotadic' zone which encompassed much of the world outside northern and western Europe. ${ }^{91}$ There is a substantial body of scholarship on the nineteenth-century European eroticization of various colonized cultures of Africa, India, South America, Southeast Asia, and the Pacific, suggesting that colonial power relations per se contributed to the new European forms of eroticization of cultural others appearing at this time. ${ }^{92}$ A similar fascination with exotic bodies and sexual practices was reflected in major works of European sexology published between $c .1880$ and $1920 .^{93}$ But less commonly recognized is the novel pharmacological interest in global aphrodisiacs that became heightened in this period, underpinned by this same eroticization of exotic others, resulting in vastly enlarged European markets for global medical products. Late nineteenth-century aphrodisiacs were part of a new configuration of sexual excess attributed to non-European others, resonating with the racist and orientalist frames that appeared in European colonizing cultures at this time. New products from multiple geographic contexts contributed to a suddenly expanded range of aphrodisiac products appearing in western European pharmacy in this time.

This expanded range is evidenced in texts such as the Materia Medica of Patna (1848), by Robert Hamilton Irvine, who was a surgeon of the British empire in India. Irvine listed some

\footnotetext{
${ }^{88}$ Newman, 'Arabic Erotic Literature', 15; Muhammad ibn 'Umar al-Nafzāwī, The Perfumed Garden of the Cheikh Nefzaoui: A manual of Arabian erotology, trans. Sir Richard Burton (London: The Kama Shastra Society, 1886); Muhammad ibn 'Umar al-Nafzāwī, 'Cheikh Nefzaoui', trans. Le Baron R., 1850, Bibliothèque Nationale de France, Paris. See also Muhammad ibn 'Umar al-Nafzāwī, 'Traduction française du "Jardin parfumé”, manuel d'érotologie arabe du XVIe par le cheikh Mohammed El-Nefzaoui', 1848, Bibliothèque Nationale de France.

${ }^{89}$ Peter M. Cryle, 'The Kama Sutra as Curriculum', in Taught Bodies, ed. C. O’Farrell, D. Meadmore, E. McWilliam, and C. Symes (New York: Peter Land, 2000), 17-25; Hsu-Ming Teo, 'Eroticising the Orient: A Survey of European Literary Representations of Cross-Cultural Encounters Between Europe and the Middle East', in Rethinking the Racial Moment: Essays on the Colonial Encounter, ed. Barbara Brookes and Alison Holland (Newcastle upon Tyne: Cambridge Scholars Publishing, 2011), 21-47.

${ }^{90}$ For instance, Richard von Krafft-Ebing, Psychopathia Sexualis mit besonderer Berücksichtigung der conträren Sexualempfindung. Eine medicinisch-gerichtliche Studie für Ärzte end Juristen, 12th ed. (Stuttgart: Verlag von Ferdinand Enke, 1903), 70-9.

${ }^{91}$ Richard F. Burton, The Book of the Thousand Nights and A Night (New York: Burton Society: 1886), 10:123, 200, $238-52$.

${ }^{92}$ Kelly L. Watson, Insatiable Appetites: Imperial Encounters with Cannibals in the North Atlantic World (New York: NYU Press, 2017); Ann Laura Stoler, Race and the Education of Desire: Foucault's History of Sexuality and the Colonial Order of Things (Durham, NC: Duke University Press, 1995); Anne McClintock, Imperial Leather: Race, Gender and Sexuality in the Colonial Conquest (New York: Routledge, 1995); Roy Porter, 'The Exotic as Erotic: Captain Cook in Tahiti', in Exoticism in the Enlightenment, ed. George S. Rousseau and Roy Porter (Manchester: Manchester University Press, 1990), 117-44; Colette Colligan, The Traffic in Obscenity from Byron to Beardsley: Sexuality and Exoticism in Nineteenth-Century Print Culture (Basingstoke: Palgrave, 2006); also Anjali Arondekar, 'Without a Trace: Sexuality and the Colonial Archive', Journal of the History of Sexuality 14, no. 1-2 (2005): 10-27; Lenore Manderson, 'Colonial Desires: Sexuality, Race and Gender in British Malaysia', Journal of the History of Sexuality 7, no. 3 (1997): 372-88.

${ }^{93}$ Fuechtner, Haynes, and Jones, eds., Global History of Sexual Science; Jana Funke, 'Navigating the Past: Sexuality, Race and the Uses of the Primitive in Magnus Hirschfeld's Travel Writings', in Sex, Knowledge, and Receptions of the Past, ed. Fisher and Langlands, 111-34.
} 
forty-one substances used in India as aphrodisiacs. Most were seen as also having a general restorative effect, or in fewer cases a narcotic or diuretic effect. They included akut choonie (a small garnet pounded into a powder), ambergris (whale resin brought from Singapore), badam (sweet almonds), bhikma root (Aconitum heterophyllum), ${ }^{94}$ kamraj root, karroba muguwi amber, maida-lakri bark and wood (Tetranthera Roxburghii), moongay ka jour (giant mustard tree root), ${ }^{95}$ ram puttire (a type of nutmeg), sikakul (wild water parsnip, salep misrie root (Orchis masula), sanda lizard oil for topical use, kadishen (Cluytia collina), kuhaila bark, and cheer-kunkol fruit. ${ }^{96}$ John Davenport's set of essays on aphrodisiacs and anti-aphrodisiacs of 1869 also referred to an array of ancient and traditional European remedies available in apothecaries, such as seraglio pastilles, tablettes de magnanimite, electuaire satyrion, poudre de foie, molluscs, truffles, musk, cantharides, and hippomanes. ${ }^{97}$ He claimed that mandrake was the most ancient, ${ }^{98}$ discussed Indian bang (cannabis milk), and mentioned a type of ambergris pastille from India called cachunde. ${ }^{99}$

French pharmacists of the late nineteenth century also scoured medical sources found in new colonial contexts in East Asia. A manual of 'indigenous and exotic medicinal plants' published in 1889 and written by the French doctor and health consul to Cochin, Georges Dujardin-Beaumetz (1833-95), with a Parisian chemist named Ed Égasse, listed a large number of purportedly aphrodisiac products that Égasse had procured from various European colonial sources. ${ }^{100}$ These included galangal from Indochina, assa foetida from India, ginger from throughout Asia, ${ }^{101}$ ginseng from China, ${ }^{102}$ and damiana from South America. ${ }^{103}$ The accounts of early modern European physicians who had travelled to the Middle East and India also attracted new translations by orientalists in the last decades of the nineteenth century, reviving forgotten knowledge of the cultural origins of substances that had now long been used as aphrodisiacs in European apothecaries. ${ }^{104}$

German colonial expansion into West Africa at the end of the nineteenth century similarly yielded new and exciting, purportedly aphrodisiac, medicinal substances. In 1896, a German chemist named Spiegel obtained a sample of yohimbe bark (Pausinystalia johimbe) which was held to be an aphrodisiac in Cameroon, and extracted an alkaloid from it which he named yohimbine. ${ }^{105}$ In 1900, it was tested and found to have a pro-sexual effect on several different kinds of mammals by the German physiologist Adolf Loewy (1862-1937), building on some initial animal research conducted by another German physiologist named Oberwarth. ${ }^{106}$ The San Francisco genito-urinary surgeon Victor Vecki, who wrote a book about impotence and was a contemporary of Loewy, dismissed yohimbine as an aphrodisiac on the grounds that people are not mice, nor cats, nor dogs, and without human research it could not be recommended. ${ }^{107}$ The German sexologist and historian Iwan Bloch nonetheless still spoke highly of it as a remedy

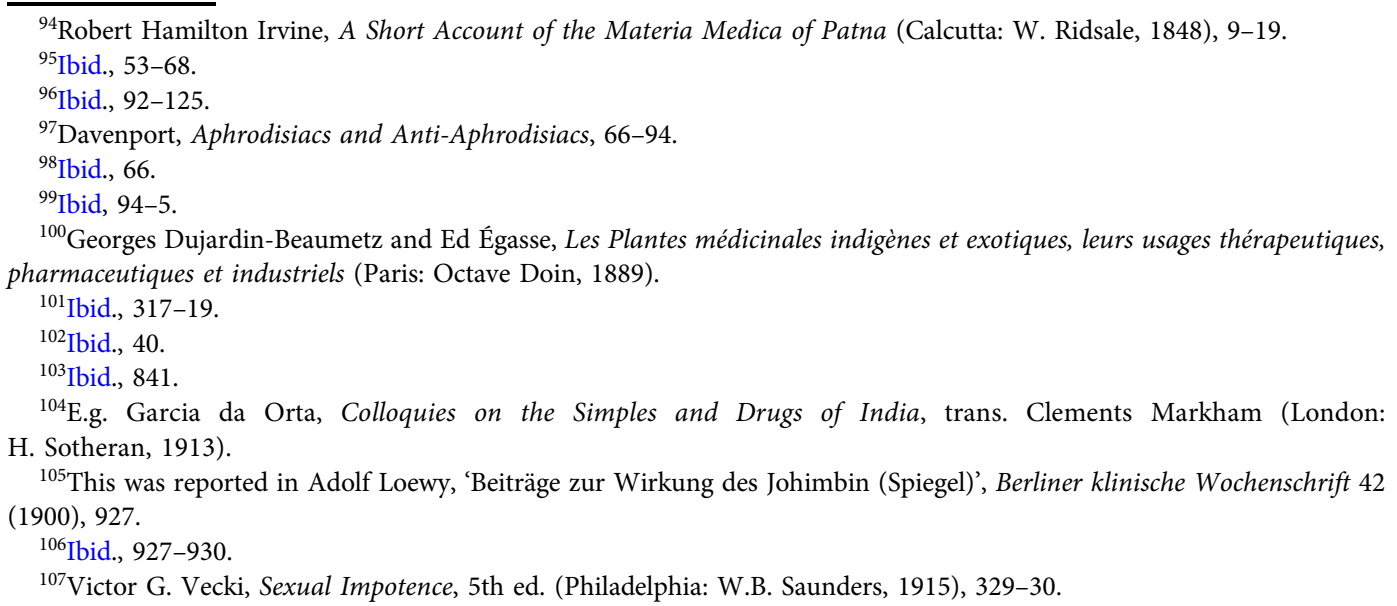


for erectile dysfunction in $1908 .^{108}$ It was also mentioned as a safe aphrodisiac in a 1906 French directory of new medications. ${ }^{109}$

The American physicians W. C. Waugh and W. F. Abbot in a 1904 textbook on alkaloid therapeutics claimed that some human research had actually been conducted on yohimbine by a physiologist called Berger, who had established that, while it is strictly limited in aphrodisiac effect to the stimulation of erection and producing congestion of the penis ... It is absolutely devoid of any power to arouse or increase sexual desire. ${ }^{110}$ Nonetheless, it was sold in pro-sexual formulas prescribed for male erectile dysfunction in America until the 1950s, such as the product called Afrodex (containing strychnine, yohimbine, and methyl testosterone), which appears still to have evoked yohimbine's exotic African origins. This was sold from at least the 1940s until the 1960 amendment of the Federal Food, Drug, and Cosmetic Act, which forced many such products off the American market. ${ }^{11}$ A new spate of human studies since the 1990s has revived interest in yohimbine globally, as well as raising concerns about its safety. ${ }^{112}$ Today, yohimbine's appeal seems more invested in modern scientific validation than in its exoticism, and is more focused on its athletic, rather than aphrodisiac, effects. Nonetheless, its origins lie in the late nineteenth-century German colonial exploitation of West Africa and the exoticism with which aphrodisiacs were imbued at this time.

Despite the increased range of commercial aphrodisiacs derived from colonial trade in the nineteenth century and their continued citation in apothecary lists and pharmacopoeias, we do not find much discussion of such substances in general medical textbooks between $c .1865$ and $c .1920$, nor in most works of sexual science dealing with urology, gynaecology, impotence, sterility, or frigidity, where one might expect to see some consideration of them, given their common usage. In the few texts of this period where they were discussed briefly, it was generally to dismiss or rebuke them - not just specific purported aphrodisiacs, but the whole idea per se that any medicine could safely stimulate sexual desire or pleasure. Both the French doctor Félix Roubaud, writing in 1876, and the American physician William Hammond, writing in 1885, flatly rejected the notion that any aphrodisiacs could be useful in treating the condition of women's frigidity. ${ }^{113}$ Roubaud considered that aphrodisiacs were a relic of the pre-scientific past and expressed satisfaction that their use had been abandoned by modern medicine. ${ }^{114}$ Hammond denied that they had any value either for frigidity in women or impotence in men, and preferred in every instance to use manual or electrical stimuli to reawaken slumbering genitalia. ${ }^{115}$ These clinicians were clearly not averse to rekindling sexual interest in both sexes; they simply did not consider aphrodisiacs capable of achieving that end.

In 1909, the American urologist Victor Vecki published an article in the American Journal of Urology on 'the new aphrodisiacs', referring to the very products that had flooded European and American markets as a result of colonial trade. Here Vecki explained his reasons for concluding

\footnotetext{
${ }^{108}$ Iwan Bloch, Das Sexualleben unserer Zeit in seinen Beziehungen zur modernen Kultur, 2nd ed. (Berlin: Louis Marcus, 1907), 501

${ }^{109} \mathrm{H}$. Boquillon-Limousin, Formulaire des médicament nouveaux (Paris: J.B. Baillère, 1906), 307-8.

${ }^{110}$ W. C. Waugh and W. F. Abbot, A Textbook of Alkaloid Therapeutics (Chicago: The Clinic Publishing Co., 1904), $366-8$.

${ }^{111}$ Joseph M. Betz, 'Yohimbe', in Encyclopedia of Dietary Supplements, ed. Paul M. Coates, Joseph M. Betz, Marc R. Blackman, Gordon M. Craig, Mark Levine, Joel Moss, and Jeffrey D. White (Boca Raton, FL: CRC Pess, 2015 ), 862.

${ }^{112}$ EFSA Panel on Food Additives and Nutrient Sources Added to Food, 2013, 'Scientific Opinion on the Evaluation of the Safety in Use of Yohimbe (Pausinystalia yohimbe (K. Schum.) Pierre ex Beille), EFSA Journal 11, no. 7 (2013): 3302-48, https://doi.org/10.2903/j.efsa.2013.3302.

${ }^{113}$ Félix Roubaud, Traité de l'impuissance et de la stérilité chez l'homme et chez la femme, comprenant l'exposition des moyens recommandés pour y remédier (Paris: J.-B. Baillière, 1876), 113-14; William A. Hammond, Sexual Impotence in the Male and Female (Detroit: George S. Davis, 1887), 200-13.

${ }^{114}$ Roubaud, Traité de l'impuissance, 113.

${ }^{115}$ Hammond, Sexual Impotence in the Male and Female, 91-2.
} 
'that there is no such thing as an aphrodisiac'. ${ }^{116}$ He was certainly not opposed to the search for such substances, adding that patient 'demand for a true and real aphrodisiac is great ... whenever I meet a case of so-called psychic, neurasthenic or even paralytic impotence I always wish I had a good aphrodisiac to give.'. ${ }^{17}$ He explained his experimentation with yohimbine on several of his patients, none of whom had reported any effect from the substance, aside from fainting and nausea which had alarmed one man's wife. Vecki was baffled how other esteemed colleagues had found it to be of any use, admitting that variations in the strength and quality of the extracts could be responsible. ${ }^{118}$ Despite his scepticism, he reported continuing with his own investigations with other exotic substances, such as Brazilian muira puama which he also found ineffective, and another Brazilian fluid of cantuaba which he was yet to try. He was fairly sure it would not work either but refused to give up the search for something that did. ${ }^{119}$ In 1919 the Chicago physician Henri Stearns Denninger published a short history of aphrodisiacs in the Annals of Medical History which was on the whole enthusiastic about the idea of them. Nonetheless, he too remarked that 'at the present time the status of aphrodisiacs is quite problematic, as contemporary authors cannot agree as to the efficacy of the substances used'. ${ }^{120}$

An anonymous French essay surveying the history of aphrodisiacs and appearing in 1897, produced by the French publisher of erotic texts and works of vulgarized sexual medicine Charles Carrington, discussed the use of aphrodisiacs in European medicine from the seventeenth century to the mid nineteenth century, bemoaning the loss of esteem for them in medicine in the final three decades of the nineteenth century. ${ }^{121}$ The author claimed that they had arisen historically from the need of ageing men in polygamous and slave-owning societies of the Middle East to service all their wives and/or slaves sexually, and fell into disuse in modern France owing to the desire of women to have fewer children, and so to have less sex. Aside from typically orientalist historical speculations, the author identified a loss of confidence in aphrodisiacs among doctors after 1865, adding that 'many doctors are of the opinion that there is no such thing as a true aphrodisiac', and that, if they did exist, it would be unwise for older men to sap their energy by artificially stimulating venery. ${ }^{122}$

This account of the medical disfavour into which aphrodisiacs had fallen certainly appears confirmed by Vecki's scepticism and Denninger's pessimism above. But it also aligns with a wide array of medical texts of the late nineteenth and early twentieth centuries that discussed sexual matters in older people, frequently recommending that women after menopause and men after the age of sixty should refrain from sexual activity since it was thought to weaken them. ${ }^{123}$ A 1909 French work on Menstruation in the Critical Age by a doctor Rhazis (which was one of the many pseudonyms of the French pornographer and medical vulgarizer Jean Fauconney) recommended that women have 'the courage to renounce coitus' after menopause. ${ }^{124}$ Even the anonymous author of 1897 had expressed the view that, if 'a man temporarily gains the power of indulgence by the use of drugs or certain foods, he is certainly impairing his general health'. While this indicated the common nineteenth-century view of sexual energy as the very life force of the body,

\footnotetext{
${ }^{116}$ Victor Vecki, 'The New Aphrodisiacs', American Journal of Urology 5, no. 1 (1909), 196.

${ }^{117}$ Ibid., 195.

${ }^{118}$ Ibid., 198-9.

${ }^{119}$ Ibid., 200.

${ }^{120}$ Henri Stearns Denninger, 'A History of Substances Known as Aphrodisiacs', Annals of Medical History 2, no. 4 (1919), 383-93.

121'Aphrodisiacs, Their Nature, History and Uses', 5-22.

${ }^{122}$ Ibid., 8-9.

${ }^{123}$ Alison M. Downham Moore, 'The French Elaboration of Ideas about Menopause, Sexuality and Ageing 1805-1920', French History and Civilization 8, Papers from the George Rudé Seminar (2019): 34-50.

${ }^{124}$ Le docteur Rhazis, La Menstruation et l'âge critique; causes des règles - complications. La ménopause. Début et caractère (Paris: De Porter, 1909), 87-8.
} 
which was finite and prone to depletion through ejaculation, there was also a new idea about ageing that appeared in the following passage:

On the whole, it may be said that if when a man is in bed with a pretty woman who is not only able and willing to take her own share in the sports of love, but also skilled in the arts of Venus, and he finds himself still unable to procure 'the outward and visible sign of virility' ... he had better retire from the unequal conflict and content himself with the memory of his former prowess. ${ }^{125}$

Certainly, aphrodisiacs appealed to people of many ages, not merely those over a certain age. But the emergence of negative proscriptive advice about sex for older adults in this period must have played a role in the loss of esteem that medical practitioners now had for such substances. Unsurprisingly, then, the resurgence of sexologists' enthusiasm for aphrodisiacs after 1920 was also accompanied by a deeper consideration of older adults' sexual possibilities. Magnus Hirschfeld, writing in the 1930s, was able both to enjoin older adults toward sexual pleasure and to recommend testicular-extract-containing Titus pearls as an aphrodisiac. ${ }^{126}$ But in the period between $c .1865$ and $c .1920$, such recommendations were rare on both counts: among the sexual scientists of this era, only the idiosyncratic Iwan Bloch appears to have embraced aphrodisiacs (yohimbe), most likely because he was also himself a sexuality historian who had studied aphrodisiac practices of the past. ${ }^{127}$

The negative medical view of aphrodisiacs appears to have been most pronounced from around 1865 until 1920, after which both the new liberal sexology currents, represented by figures such as Hirschfeld and Marie Stopes, and the flourishing of new research into isolated hormonal interventions turned the tide of medical practitioners again towards prescribing pro-sexual substances. Aphrodisiacs were probably held in contempt by most medical practitioners between $c .1865$ and $c .1920$ for other reasons as well. In the second half of the nineteenth century, there was a veritable flood of new products, derived from new colonial trade and purporting to have aphrodisiac effects, but which had never been tested by European pharmacists or clinicians. As Vecki had suspected, the authenticity and potency of such products probably varied wildly in so far as they had any pharmacological activity at the best of times, and undoubtedly left many unsatisfied customers. Secondly, there was a general boom of what came to be known as 'quack' sellers of sexual products in this period, which included various devices, elixirs, manual treatments, enemas, and advice manuals, and with which aphrodisiacs became generally associated. ${ }^{128}$ Male impotence was in fact a major target of predatory sellers of purported medicinal products at this time in both England and the US, spurred on by a blossoming medical scholarship on impotence and sterility. ${ }^{129}$ The trade in quackery in England had reached a fever pitch by the mid nineteenth century, and many doctors were dismayed at what they perceived as an array of concoctions that could be purchased from unscrupulous vendors against their own better advice. ${ }^{130}$

However, the line between respectable medicine and unscrupulous quackery was constantly shifting. Aphrodisiacs moved along an axis of demi-respectability, most often falling on the wrong side of the line in the late nineteenth century. In this period, even perfectly respectable commercial pharmacies were not always aligned with the scientific goals of medical scholars and practitioners,

\footnotetext{
${ }^{125 ‘}$ Aphrodisiacs, Their Nature, History and Uses', 10.

${ }^{126}$ Magnus Hirschfeld, Titus Perlen. Wissenschaftliches Sexual-Hormon-Präparat (Berlin: Pankow, 1932).

${ }^{127}$ Alison M. Downham Moore, 'The Historicity of Sexuality: Knowledge of the Past in the Emergence of Modern Sexual Science', Modern Intellectual History (online 2019), https://doi.org/10.1017/S147924431900026X.

${ }^{128}$ Roy Porter, Health For Sale: Quackery in England 1660-1850 (Manchester: Manchester University Press, 1989), 146-86; Angus McLaren, Impotence: A Cultural History (Chicago: University of Chicago Press, 2007), 126-48.

${ }^{129}$ McLaren, Impotence, $126-48$.

${ }^{130}$ Porter, Health For Sale, 158.
} 
and sold a large variety of substances that were reputed to have aphrodisiac effects purely on account of their pre-modern European reputation, or on account of their use for such purposes in the medical traditions of other cultures with which Europe was now in contact.

Strikingly, the official medical disapproval of aphrodisiacs in the early twentieth-century did not result in a reduction of sales. Rather, the period of peak aphrodisiac scepticism was accompanied by a steadily increasing commercial market for products of many kinds, derived from colonial trade, which purported to stimulate sexual desire, sustain erections, and increase pleasure. These were sold throughout the early twentieth century, by mail-order businesses, pharmacists, quack practitioners, and qualified medical professionals alike, showing the lines between respectable and disreputable medicine to be constantly shifting in relation to such products. Today, aphrodisiac or pro-sexual products - herbal, pharmaceutical, and hormonal - together represent a vast and truly globalized market. ${ }^{131}$ But even in the period when most medical professionals denied that it was possible to stimulate sexual desire chemically, the market for such products had begun its first massive global expansion. Aside from the expanded apothecary lists such as those already cited here, advertisements for these products sometimes even appeared in general French and American newspapers between 1890 and $1920{ }^{132}$

Nonetheless, by the end of the nineteenth century, the very concept of aphrodisiacs, as a class of unique substances, had become widely discredited in official French, German, British, and American biomedicine, with few doctors willing to prescribe or recommend them in the late nineteenth and early twentieth centuries. In the late 1920s, the idea of 'pro-sexual' substances received a significant resurgence in sexology and in emergent endocrinology from the quest to identify the molecular basis of the sex-steroid hormones, as described in Chandak Sengoopta's elegant monograph The Most Secret Quintessence of Life (beyond the scope of our current article). ${ }^{133}$ The period between $c .1865$ and $c .1920$ saw the flourishing of sexual scientific writing, erotica, and prostitution, and the emergence of same-sex-desiring urban subcultures, as well as new forms of medical sympathy for same-sex-desiring people among liberal sexologists. ${ }^{134}$ So it is untenable to see the denial of aphrodisiacs in this period as a product of a general sexual conservatism by appeal to the cliché of 'Victorian prudishness'. ${ }^{135}$ Rather, the loss of medical esteem for aphrodisiacs appears bound up with the very exoticist reputation attributed to them at a time when only Western biomedicine held legitimacy.

\section{Conclusion}

Our article has indicated important conceptual shifts occurring in the understanding of aphrodisiac substances between Islamicate and Christianate cultures and between early and late modern western European forms: Many early modern European remedies specifically focused on women's and men's fertility, while nineteenth- and early twentieth-century aphrodisiac products typically targeted sexual desire, especially male erection, but not conception. We have found scant reference in early modern medical sources to the use of such substances to treat ageing men's libido, though,

\footnotetext{
${ }^{131}$ Erectile dysfunction drugs alone represented a global share market value of US $\$ 4.39$ billion in 2014. Grand View Research Inc., 'Erectile Dysfunction Drugs Market Analysis by Product (Viagra, Levitra/Staxyn, Stendra/Spedra, Zydena, Vitaros), and Segment Forecasts to 2022' (July 2016), https://www.grandviewresearch.com/industry-analysis/erectiledysfunction-drugs-market.

${ }^{132}$ E.g. viris lucet was an aphrodisiac extract advertised in the French satirical weekly newspaper Jean qui rit: journal illustré paraissant le vendredi, 29 March 1914, 14. A purportedly 'Mexican damiana bitters' product was advertised in the American daily newspaper San Francisco Call, 30 August 1899, 2.

${ }^{133}$ Chandak Sengoopta, The Most Secret Quintessence of Life: Sex, Glands, and Hormones, 1850-1950 (Chicago: Chicago University Press, 2006).

${ }^{134}$ Johanna Alberti, 'The Turn of the Tide: Sexuality and Politics, 1928-31', Women's History Review 3, no. 2 (1994): 169-90.

${ }^{135}$ See Lesley A. Hall, 'The Victorians: Our Others, Our Selves?', in Sex, Knowledge, and Reception of the Past, ed. Fisher and Langlands, 160-76; Moore, 'Victorian Medicine', 53-81.
} 
rarely, early modern European literary sources referred to old men imbibing 'provokers of venery', usually as a comic trope. ${ }^{136}$ But in the late nineteenth and early twentieth centuries, the intended use of aphrodisiacs to treat ageing sexuality was indeed specifically discussed in medical sources, and in (heavily elaborated) European translations of medieval Arabic texts of sexual science. ${ }^{137}$ Nineteenth-century aphrodisiacs were specifically exoticist and were driven by the new global exchange of goods associated with European colonial and imperial expansion in Asia, Africa, and South America. Indeed, many of the currently popular herbal aphrodisiacs such as damiana and yohimbe derive from the efforts of nineteenth-century pharmacists to locate novel and exotic products that could be marketed as sexual stimulants following the view that non-Europeans were sexually excessive and so their medical traditions would be likely to contain knowledge of effective aphrodisiacs. ${ }^{138}$

From the body of excellent existing specialist studies that we have cited here, aphrodisiacs have clearly referred to different substances and contained different ideation in all of the historical contexts where they have been described. They are anything but a historical constant and appear subject to spectacular variation, while also containing significant global entanglements that have so far been little studied. These are not questions of purely antiquarian interest: the inscription of aphrodisiacs into forms of colonial exoticism has continued well beyond the period of our survey here, featuring for instance in the 1970 orientalist novel by Allen Edwardes and R. E. L. Masters, The Cradle of Erotica. ${ }^{139}$ At the same time, the aphrodisiacs of old (as distinct from hormonal products and pharmaceuticals such as Viagra) remain discredited in biomedicine. ${ }^{140}$ It is hoped that our present contribution to the historiography of aphrodisiacs will open new lines of inquiry for researchers in the global history of sexuality, pharmacy, botany, and medicine. Our article has also gestured toward an emerging research field that considers the global exchanges of knowledge and medical substances as formative in the history of scientific understandings of physiology and in larger conceptions of sexual desire. Such lines of inquiry have an important role to play in destabilizing the habits of thought that continue to misguide historians by priming us only to notice how the West impacts other cultures. The global history of aphrodisiacs shows us instead how we might attend to the way in which knowledge systems characterized as 'Western' were informed by multiple temporal transmissions and intercultural entanglements of the past. At the same time, it shows how transformation of knowledge from one context to another can produce profound changes in conceptions of the body.

Alison M. Downham Moore is Associate Professor of History at Western Sydney University, Australia, as well as a Marie Skłodowska-Curie Senior Research Fellow at Freiburg Institute for Advanced Studies, and Research Fellow at the Hanse Wissenschaftskolleg, both in Germany. She is author of Sexual Myths of Modernity: Sadism, Masochism and Historical Teleology (2016) and author with Peter Cryle of Frigidity, an Intellectual History (2011).

Rashmi Pithavadian is a sessional academic and research officer in the School of Health Sciences at Western Sydney University. She is also a Master of Research candidate completing a project on ‘Understanding women's experiences of seeking help for vaginismus: Implications for their perceived sense of self.

\footnotetext{
${ }^{136}$ Laura Giannetti, 'The Satyr in the Kitchen Pantry', in Cuckoldry, Impotence and Adultery in Europe (15th-17th century), ed. Sara Matthews-Grieco (Farnham: Ashgate, 2014), 103-24.

${ }^{137}$ E.g. Jâlal-ad-Din as-Siyuti, Kitab al-Izah fi'Ilm al Nikab b-it-Tamam w-al-Kamal (Book of Exposition: The Secrets of Oriental Sexology), trans. 'An English Bohemian' (Paris: Maison d'Éditions Scientifiques, 1900).

${ }^{138}$ E.g. Denninger, 'History of Substances Known as Aphrodisiacs', 383-93.

${ }^{139}$ Allen Edwardes and R. E. L. Masters, The Cradle of Erotica: A Study of Afro-Asian Sexual Expression and an Analysis of Erotic Freedom in Social Relationships (London: The Odyssey Press, 1970), 61-3.

${ }^{140}$ Frank H. Gawin, 'Pharmacologic Enhancement of the Erotic: Implications of an Expanded Definition of Aphrodisiacs', Journal of Sex Research 14, no. 2 (1978): 107-17.
} 